\section{Histoplasmose disseminada e síndrome de imunodeficiência adquirida. Estudo clínico- laboratorial de 28 casos}

Com o objetivo de estudar o quadro clínicolaboratorial da histoplasmose disseminada associada à síndrome de imunodeficiência adquirida, selecionamos 28 pacientes com aquela infecção fúngica. Infecção oportunística, rara no início da década de 80 , este tipo de patologia fúngica tem elevado sua freqüência, em áreas endêmicas de histoplasmose, como conseqüência da pandemia da síndrome de imunodeficiência adquirida (AIDS). Neste resumo destacamos a história da histoplasmose clássica e africana, seus agentes etiológicos, as características morfobiológicas mais importantes do Histoplasma capsulatum var. capsulatum e var. duboisii, bem como sua ecologia e epidemiologia. Os marcos fundamentais no estudo da histoplasmose foram destacados com uma avaliação do quadro clínico do paciente imunocompetente e imunocomprometido. Analisamos o diagnóstico laboratorial e destacamos a importância do exame histopatológico, do isolamento e identificação do fungo e das provas sorológicas na revelação de anticorpos e antígenos circulantes. A viabilidade do tratamento destes casos com drogas antifúngicas disponíveis, mostra que um diagnóstico precoce desta associação pode conduzir a uma cura clínica e micológica. Dados epidemiológicos sugerem que a fonte de infecção da histoplasmose em metade dos casos tenha sido contato com fezes de galinhas. Febre, perda de peso, dispnéia e lesões cutâneas disseminadas, adenomegalias, hepatomegalia e esplenomegalia foram evidentes, bem como infiltração intersticial difusa dos pulmões. A histoplasmose disseminada deve fazer parte do diagnóstico diferencial de todo paciente com AIDS que apresente alguns desses sinais ou sintomas. Nossos resultados demonstravam o valor da histopatologia, sorologia (pesquisa de anticorpos) e cultura na busca de um diagnóstico específico, especialmente, nos pacientes com AIDS.

\section{Disseminated histoplasmosis associated with immunodeficiency syndrome. A clinical-laboratory study of 28 cases}

With the purpose of studying the clinical and laboratoirial situation of disseminated histoplasmosis associated with acquired immunodeficiency syndrome, we studied 28 AIDS patients with this fungal infection. This opportunistic infection was rare in the beginning of the 1980's but the frequency of this fungal pathogen has increased in many areas where histoplasmosis is endemic as a consequence of the aquired immunodeficiency syndrome (AIDS) pandemic. In this summary, we emphasized the history of classical and African histoplasmosis, their etiological agents, the more important morphobiological characteristics of Histoplasma capsulatum var. capsulatum and var. duboisil, as well as their ecology and epidemiology. The fundamental points of the classical and African histoplasmosis were emphasized by comparing and contrasting the clinical presentation in immuno-competent and immunocompromissed patients. We analyzed laboratory diagnosis and emphasized the importance of histopathological examination, the isolation and identification of the fungal species, measurement of circulating antibodies and antigens. The yield of treatment with the antifungal currently available drugs indicates that early diagnosis offers the best prospect of achieving a clinical and mycological cure. Epidemiological data suggest aerosolized fowl excrement is the likely source of some cases of histoplasmosis infection. Fever, weight loss, shortness of breath and disseminated cutaneous lesions, lymphadenopathy, hepatomegaly, splenomegaly and pulmonary intersticial infiltration were common clinical features of the cases. Disseminated histoplasmosis must be part of the differential diagnosis in all patients with AIDS that show any of these signs or symptoms. Our results show the value of histopathology, serology and fungal culture in the pursuit of a specific diagnosis especially in AIDS patients.

Katia de Souza Alves

Dissertação apresentada à Faculdade de Medicina da Universidade de São Paulo para obtenção do Título de Mestre.

São Paulo, SP, Brasil, 1996.

Recebido para publicação em 06/04/98. 